\title{
REFLEKSIJA PAR VĒRTĪBĀM TAGADNES KONTEKSTĀ
}
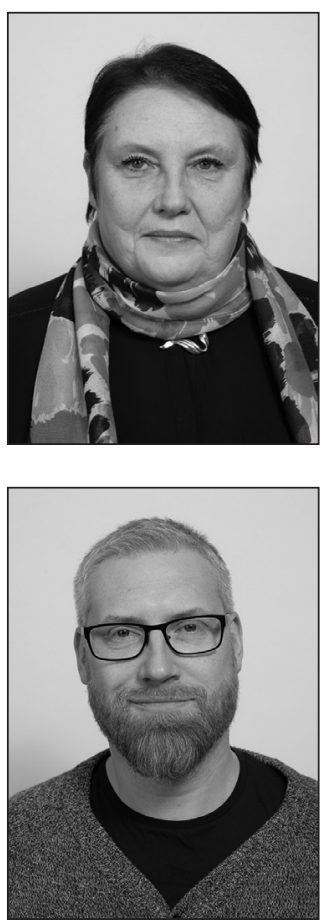

Vija Sīle ir Rīgas Stradiņa universitātes Humanitāro zinātņu katedras profesore. Strādā par lektori veselības aprūpes, kā arī sociālo zinātṇu jomā. Lasa kursus par medic̄̄nas, juridiskās un komunikācijas ētikas tēmām, īpašu uzmanību veltot ētikai politikā un valsts pārvaldē. Ir rakstu autore par filozofiskās antropologijias un ētikas aktuālām problēmām. Pētnieciskās intereses: bioētika un pētniecības ētika, filozofiskās antropolog̣ijas problemātika, mūsdienu sociālās teorijas.

Vents Sīlis ir Rīgas Stradiṇa universitātes Humanitāro zinātṇu katedras docētājs. Lasa kursus par pētniecības ētiku, filozofisko antropoloǵiju, politisko antropoloǵiju, seksualitāti, apzinātību, kā arī ārprāta antropoloǵiju un personības psiholoǵiju. Nodarbojas ar vīru grupu organizāciju un vīriešu pašidentifikācijas problēmām mūsdienu Latvijā. Pētnieciskās intereses: antropologija, seksualitāte, bioētika un modernā maskulinitāte.
Raksturvārdi: vērtības, vērtību objektivitāte, vērtību relatīvisms, autonomija, multikulturālisms, tolerance, dzīvesstāsti.

\section{Ievads}

Tā ir nejauši sakritis, ka refleksija par vērtībām noris laikā, kad Eiropa svin Romas līguma sešdesmito gadadienu. 1958. gada 1. janvārī stājās spēkā Eiropas Kopienas dibināšanas līgums, kuru Romā bija parakstījušas pirmās sešas dalībvalstis. Tas bija vitāli nepieciešams līgums, lai pasaules karu plosītā Eiropa atgūtu ne tikai mieru, bet arī ekonomisko stabilitāti, balstoties uz vienotu tirgu un brīvu labumu plūsmu ne tikai starp šìm sešām valstīm. Eiropas Savienība (tagad jau kā 28 valstu kopa) ir pāraugusi savu pamatmērķi - veicināt harmonisku saimnieciskās darbības attīstību, pastāvīgu un līdzsvarotu izaugsmi, lielāku stabilitāti, straujāku dzīves līmeņa paaugstināšanos un ciešākas attiecības starp dalībvalstīm. Tā ir ne tikai ekonomiska savienība, jo "Vienoti daudzveidībā" ir kaut kas vairāk par ideoloǵisku lozungu - šī dažādība ir eiropeiska vērtība, uzsver politologi Ž. Ozoliņa, G. Puriņš, I. İjabs u. c.

Eiropas Savienība ir dibināta, pamatojoties uz tādām vērtībām kā cilvēka cieña, brīvība, demokrātija, vienlīdzība, tiesiskums 
un cilvēktiesības, tostarp minoritāšu tiesības. Šìs vērtības dalībvalstīm ir kopīgas sabiedrībā, kur valda plurālisms, tolerance, taisnīgums, solidaritāte un kur nav diskriminācijas, kā arī valda dzimumu līdztiesība.

Vērtības balsta cita citu, periodiski mainoties no līdzekḷiem citu vērtību sasniegšanai uz vērtībām kā mērḳiem. Tās ir brīnišḳīgas humānisma vērtības, kuras tika deklarētas vēsturiski sarežǵîtā situācijā: "Eiropas Savienība ir veidojusies pēckara pasaulē laikā, kad Rietumos sevi diskreditējuši lielie, totalitārie "vērtību projekti". Vēl nesen "eiropeiskās kultūras saglabāšanas" un "strādnieku škiras atbrīvošanas vārdā" masveidīgi tika iznīcināti cilvēki. Stingras vērtības un mēǵinājumi tām konsekventi sekot bija novedušas Eiropas civilizāciju uz iznīcības robežas."

Tajā pašā laikā ir acīmredzams, ka Eiropas Savienības veidošanās un tālākā attīstība ir vēl viens lielais "vērtību projekts". Proti, tieši diskusija par vērtībām palīdzēja Eiropas valstīm gan pārvarēt totalitārisma un pasaules karu sekas, gan arī nonākt pie idejas par Eiropas Savienību. Paraugoties atpakal vēsturē, nav grūti konstatēt, ka jebkura diža civilizācija radās un uzplauka, pateicoties konkrētu vērtību praksei, un gāja bojā, pateicoties tam, ka tā pārstāja praktizēt savas fundamentālās vērtības. Reflektējot par sengrieḳu civilizācijas norietu, Bērtrands Rasels par pagrimuma iemeslu uzskata to, ka "loti augsts civilizācijas līmenis tika apvienots ar l,oti zemu morāles līmeni". ${ }^{2}$ Tādā veidā tika pakāpeniski izšḳērdēts konkrētās sabiedrības sociālais kapitāls, kas veda pie tās novājināšanās un sabrukuma.

Lai saprastu Eiropas Savienības vērtību projekta lokālo diskursu, ir jāreflektē, un š̄i refleksija vienlaicīgi ietver pārdomas gan par konceptuālajām nostādnēm, gan par vērtību pētījumiem un tajos iegūtajiem rezultātiem, gan prakses reālijām aktuālo notikumu izskatā. Lai kādas nebūtu Eiropas Savienības ekonomiskās likstas, tas ir un paliek vērtību projekts visām dalībvalstīm, arī Lielbritānijai, kaut tā ir pieteikusi savu izstāšanos. Vērtību konflikti, tāpat kā terorakti, plosa ne tikai Eiropas Savienību, bet arī citas valstis, kultūras un atsevišķus

\footnotetext{
1 Ijabs 2007a, 17.

2 Russell 1938, 73.
}

indivīdus, taču tas nebūt nenozīmē, ka cilvēki ir gatavi no tām atteikties. Gluži otrādi, tas rada vēlmi aizstāvēt individuālās un kolektīiās vērtības, kuras ir būtiskas abos līmeņos. Tieši šādā kontekstā ir saprotams britu premjerministres Terēzas Mejas teiktais pēc 22. marta terorakta pie parlamenta ēkas Londonā: "Jebkuri centieni sagraut demokrātiskās vērtības ar vardarbības un terora pan̄ēmieniem ir lemti neveiksmei .. izvēelētā vieta nav sakritība, bet gan apzināta izvēle uzbrukt tieši galvaspilsētas sirdī, kurā dažādu tautību, reliğiju un kultūru cilvēki svin brīvību, demokrātiju un vārda brīvību." '3ātad notika kārtējais uzbrukums ne tikai kādai cilvēku grupai vai institūcijai, bet arī konkrētām, vārdā nosauktām vērtībām.

Vienlaikus arī paši uzbrucēji pārstāv konkrētas vērtības - karojošu, reliǵiski ietonētu ideologiiju, kas ir ārkārtīgi neiecietīga pret alternatīvām. Tas savukārt parāda, ka tikai vienas šauras un neplurālistiskas vērtību sistēmas absolutizēšana ir ceḷš uz vienkāršotu pasaules redzējumu, kur viss atšķirīgais ir nesaprotams un draudīgs. Šādu vērtību sistēmu ir vieglāk mācīt un praktizēt, taču tā veicina grupas domāšanu (groupthink) un iekšējo konformitāti.

Vērtību apzināšanās prakses un teorijas simbiozē paver jaunas kognitīvās iespējas tagadnes un nākotnes vērtību pētniekiem. Un ne tikai pētniekiem - tā ir iespēja jebkurai sabiedrībai, kas ir spējīga uz kritisko domāšanu, veikt pašapzināšanās aktu.

\section{Vērtību jēga un nozīme, vērtību relatīvisms}

Teorētiskajā līmenī vispirms ir jārunā par vērtību definēšanu. Vienu no klasiskajām vērtību definīcijām ir radījis amerikāṇu pētnieks Miltons Rokičs. Viņa izpratnē vērtība ir relatīvi stabils priekšstats par to, kādi filozofiski, sociāli, morāli, ekonomiski, politiski, estētiski un reliǵiski stāvokḷi cilvēka dzīvē un uzvedībā ir būtiskāki vai vēlamāki un kādi mazāk būtiski vai nevēlami. ${ }^{4}$ Šajā definīcijā tiek uzsvērti divi būtiski aspekti: pirmkārt, vērtības ir relatīvi stabils priekšstats, kas īsterminā saglabā savu saturisko integritāti. Tas gan nenozīmē,

\footnotetext{
3 LETA 2018.

4 Dzalbe 2015.
} 
ka vērtības vispār nemainās, taču šīs izmaiņas notiek relatīvi ilgā laika posmā - pamanāmas izmainas bieži prasa vairākas desmitgades. Ja vērtības būtu pārāk mainīgas, nebūtu iespējama nedz indivīda, nedz sabiedrības kontinuitāte, bet, ja vērtības būtu absolūti stabilas un nemainīgas, tad nebūtu iespējamas sociālas

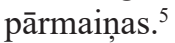

Otrkārt, vērtības ir priekšstati par stāvokḷiem, kas cilvēka dzīvē ir būtiskāki vai vēlamāki par citiem, - tādi kā laime, brīvība, mīlestība utt. Tas nozīmē, ka vērtības, no vienas puses, veido mūsu uzvedību un attieksmi pret pasauli un cilvēkiem kopumā, no otras puses, tās ir šīs attieksmes īstenojums, kas var būt saistīts ar vajadzībām, kā arī nesaistīts ar tām. Ar vajadzībām nesaistītas vērtības parādās kā "mūžīgās vērtības" jeb vērtību ideāli, kuri ir pārlaicīgi, tāpēc atrodami gandrīz visās kultūrās: dzīvības vērtība, brīvības un humānisma ideāli.

Taču vērtības nefunkcionē tikai ideālu formātā. Tās kalpo cilvēka pašrealizācijas un sabiedrības attīstības mērķiem, ja to prasa šīs sabiedrības izaugsmes vajadzības, - lai varētu īstenot noteiktas vērtības, citām jau ir jābūt sociālajā praksē. Tā, piem., liberālās vērtības var pilnvērtīgi pastāvèt tikai tādos apstākļos, kad sociālā labklājība kā vērtība jau ir iemiesota vai tiek iemiesota, proti, kad pastāv skaitliski pietiekami liels vidusšķiras slānis (statistiski vēlams ne mazāks par 25\%), kuram labklājības līmenis un izglītība l̦auj realizēt gan autonomu izvēli, gan toleranci. Trūkumā dzīvojošai sabiedrībai var rasties nopietnas grūtības tolerances veidošanā un attīstīšanā, jo nevienlīdzības plaisa ir pārāk dziḷa. Domājot ar to Rietumu sabiedrību, J. Berlins citē R. H. Tauniju (Tawney): "Brīvība līdakai nozīmē nāvi grunduḷiem.” Un turpina ar jautājumiem: ko nozīmē brīvība tiem, kuri to nevar izmantot? Kāda ir brīvības vērtība bez atbilstošiem apstākḷiem tās izmantošanai? Ir situācijas, kurās apavi ir svarīgāki par garīgajām vērtībām ne katram individuālā brīvība var būt pirmā nepieciešamība. ${ }^{7}$ Citiem vārdiem, ekonomiskā

\footnotetext{
Dzalbe 2015, 117.

6 Berlins 2000, 172

7 Turpat.
}

labklājība rada pamatu (atbilstošus apstākḷus) sociālo un kultūras vērtību realizācijai.

Lai cilvēks spētu jēgpilni eksistēt šajā pasaulē, viņam pašam jāmeklē un arī jāatrod atbilde uz jautājumu: kas ir tas, kādēl ir vērts dzīvot? Atbilde ir nepieciešama ikvienam, sākot ar indivīdu un beidzot ar nāciju. To, ka tā nav un nevar būt vienkārši rodama, apliecina cilvēku dzīvesstāsti, vēstures līkloči, nāciju likteņi, arī nonākšana līdz strupcel̦am domai par savas eksistences bezjēdzīgumu. Dažos gadījumos tas nozīmē samierināties ar to, ka dzīvei nepiemīt nekāda īpaša, sākotnēji klātesoša un no apstākḷiem neatkarīga vērtība. Šeit sakņojas nihilisma pozīcija, kas ir radikāls vērtību noliegums. Bet arī skepticisms var rezultēties ar vērtību apšaubīšanu tik lielā mērā, ka nav iespējams atbildēt uz jautājumu, kādēl ir vērts dzīvot.

Vērtības nosaka ne tikai attieksmi pret priekšmetiem un situācijām, ideolog̣iju, sevis prezentāciju ikdienas dzīvē, vērtēšanu, spriešanu, rīcības pamatošanu, bet arī cilvēka uzvedību, sevis salīdzināšanu ar citiem, citu cilvēku ietekmēšanu, kā arī palīdz cilvēkiem pielāgoties, iegūt zināšanas, saglabāt savu patību un īstenot to. Domājot par vērtību veidiem, ir svarīgi nošķirt vērtības $k \bar{a}$ lìdzekli kādu citu mērķu sasniegšanai no vērtībām kā mērķa paša par sevi. Šo nošķīumu veic V. V. Klīve, analizējot morālo vērtību būtību. Ekstrinsiskās morālās vērtības ir līdzekḷi zināmu mērḳu sasniegšanai, galvenokārt lai sasniegtu to, kas ir labs. Savukārt intrinsiskās vērtības ir labas pašas par sevi, jo tām piemīt būtiskas iezīmes, kas padara tās par neapšaubāmām vērtībām cilvēka eksistences kontekstā. Tās ir mūsu augstākie mērkii. ${ }^{8}$ Ja vērtības ir mērḳis pašas par sevi, jo indivīds vēlas tās iemiesot savā dzīves gaitā, piedzīvot, ka tās tiek īstenotas savstarpējās attiecībās, tad tās var kḷūt par dzīves organizācijas principiem, sākot ar indivīdu un beidzot ar nāciju un tās kultūru. Vislielākās grūtības indivīdam rodas situācijās, kad pašam ir jānosaka, kas ir un kas nav vērtība.

Vienkāršotā veidā var teikt, ka vērtība ir tas, ko par vērtību uzskata ne tikai konkrēts indivīds, bet arī citi cilvēki. Izpratne par vērtībām

8 Klìve 1998, 52-53. 
un to savstarpējo sakarību ietilpst cilvēka sociālās izglītības procesā, jo vērtības neveidojas pašas no sevis, tās tiek iemācìtas - vērtības ir socializācijas līdzeklis, tāpēc audzināšana vērtību gaisotnē allaž sagādā zināmas problēmas abām pusēm: audzinātājiem un audzināmajiem. Sociālas, personiskās un kultūras pieredzes iespaidā vērtības tiek internalizētas, veidojot psiholoǵisku struktūru, kura organizē cilvēka sociālo uzvedību. Tās kalpo par kritērijiem jeb standartiem, ar kuru palīdzību cilvēks orientējas gan iekšējā, gan ārējā pasaulē, tāpēc vērtību un vērtību sistēmu izpētei ir liela nozīme cilvēka psihes satura un dinamikas izpratnes veicināšanā.

Bērna attīstības sākumposmā vērtības tiek mācītas pakāpeniski, pa vienai, un, lai padarītu šo procesu vēl efektīvāku, tās tiek pasniegtas galējā, absolutizētā formā (kā tas ir, piem., pasakās, kuras pieaugušo uztverē var izskatīties naivas). Tādā veidā bērns vispirms iemācās atpazìt atsevišḳas vērtības šaurā konkrētā situācijā. Attīstībai turpinoties, priekšstats par vērtībām pamazām kḷūst arvien kompleksāks, jo bērnam nākas sastapties ar sociālām situācijām, kurās parādās vairākas savstarpēji konkurējošas vērtības.

Nākamais solis ietver prasmi integrēt atsevišķās vērtības plašākā kontekstā, kur ir nepieciešama dažādu vērtību savstarpēja pozicionēšana. Tādā veidā tiek veidota un nostiprināta sistemātiska hierarhija, kurā katras atseviškās vērtības vietu nosaka tās attiecība pret citām vērtībām, tādējādi iedalot tās svarīgākajās un mazāk svarīgajās. ${ }^{9}$ Līdz ar to ir iespējams nodalìt augstāka un zemāka līmeṇa baudas.

Bauda kā vērtība ir ḷoti atškirīgi interpretējams fenomens. Patēriṇa kultūras apstākḷıs bauda un labsajūta ir fundamentāla vērtība, kas tiek iegūta par naudu. Mārketinga un reklāmas industrija patērētājā ir atmodinājusi baudītāju un turpina uzturēt vajadzību būt tādam. Tā ir vēl viena liecība tam, ka vērtību relatīvisms vienlaicīgi ir universāla parādība un nemain̄̄gi aktuāla problēma. Tā tradicionāli aktualizējas pārejas tipa sabiedrībās vai pārejas periodos.

9 Klīve 1998, 116.
J. N. Vējš, pētot vērtību problemātiku Latvijas kontekstā, ${ }^{10}$ pamatoti norāda uz to, ka religíijas, moralitātes un vērtību problemātika vienmēr ir bijusi klātesoša Latvijas garīgajā dzīvē un intelektuālajā diskursā, kurā nozīmīga personība ir Jesaja Berlins kā eiropeisko liberālo vērtību iedibinātājs. Lai izvairītos no vērtību relatīvisma vulgarizācijas - uzskata, ka liberālās vērtības ir gandrīz vai sinonīms normatīvai visatļautībai, - ir jāatceras, ka, pēc J. Berlina viedokḷa, dažādu kultūru vērtības var nesakrist un var izvērsties vērtību konflikts pat vienas kultūras ietvaros vai, iespējams, viena cilvēka uzskatos dažādos viņa dz̄ives periodos vai pat vienā laikā, bet tas neliecina par vērtību relatīvismu. Gluži otrādi, tas liecina par hierarhiski nestrukturizētu vērtību plurālismu. J. Berlina vērtību plurālisma doktrīna balstās uz tolerances principa atzīšanas nepieciešamību. Būt tolerantam nozīmē pieņemt to, kas citādi būtu pilnīgi nepieņemams vai neciešams. Novērtējot Berlina devumu tolerances jomā, tiek uzsvērts, ka "nepareizie" viedokḷi nav vienkārši jāpiecieš, bet gan jāiemācās tos uzlūkot par citas kultūras sistēmiskā veseluma dalu. Tieši vērtības ir tās, kas parāda, ka nav vienas vienīgās patiesības, ka tikai vienas vien̄̄gās un absolūtās patiesības atzišana ir ne vien ceḷš uz dogmatismu, bet arī prāta bezdibenis - aprobežotība, kas savās radikālisma izpausmēs ir bīstama sev un citiem. Kā raksta J. Berlins, "ja es zinu patieso atbildi, bet tu to nezini un man nepiekrīit, tad tas ir tāpēc, ka tu esi nezinošs; ja tu zinātu patiesību, tu noteikti ticētu tam, kam ticu es; ja tu gribi man pretoties, tad tikai tāpēc, ka tu maldies, jo tev nav atklājusies patiesība tā, kā tā ir atklājusies man. Šāda pieeja attaisno visatbaidošākos apspiešanas un paverdzināšanas veidus cilvēces vēsturē, un tā patiešām ir pati bīstamākā un, jo sevišksi mūsu gadsimtā, pati vardarbīgākā pozitīvās brīvības jēdziena interpretācija". ${ }^{11}$ Lìdz ar to vērtību plurālisms neizbēgami tiek konfrontêts ar monismu, kas noved pie nepieciešamības izdarìt galīgo izvēli: ja tiek izvēlēts plurālisms, tad liberālās vērtības, bet, ja ir izvēlēts monisms, tad konservatīiās vērtības. Maldīgs ir priekšstats, ka atškikirīgās vērtīborientācijas ir

\footnotetext{
${ }^{10}$ Vējš 2016.

${ }^{11}$ Berlins 1996a.
} 
spējīgas bez domstarpībām sadzīvot mūsdienu Eiropā: "orientācija uz politisko plurālismu ir disonējusi ar nacionālismu, savukārt sociālās solidaritātes prasība ir atradusies opozīcijā indivīda brīvības un nopelnu vērtībai. Tieši dažādo vērtīborientāciju nesaskaņas, konflikti un kompromisi ir veidojuši Eiropai raksturīgo pasaules uzskatu". ${ }^{12}$ Citiem vārdiem - domstarpỉbas ir ne tikai neizbēgamas, bet pat vēlamas, jo ḷauj katram diskusijas dalībniekam pārbaudīt un precizēt savas pozīcijas.

Kultūras relatīvisms ir saturiski šaurāks jēdziens nekā vērtību relatīvisms, taču samērā plaši izplatîts un pragmatiski lietots gan ikdienas apziņas līmenī, gan teorētiskajā līmenī. Arī tam piemīt negatīva nokrāsa, jo tiek uzsvērta jebkuras kultūras pašpietiekamība un nesamērojamība ar citām kultūrām. Līdz ar to apriori tiek postulēts, ka kultūras savdabība nevar kḷūt par pamatu tādu komunikācijas dalībnieku savstarpējai sapratnei, kuri nākuši no dažādām kultūrtelpām, - ir iespējama tikai virzība blakus, bet pa paralēliem celiṇiem. Turpretī literatūras un mākslas jomā globalizācijas iespaidā valda kultūru mijiedarbība, kuru apzīmē ar jēdzienu "interkulturālisms". Veidojas savdabīga kultūras procesa mūsdienu aina - divas pretējas attīstības tendences vienlaicīgi, bet tās jau apzīmē jēdziens "transkulturālisms" - aizgūto nozīmju izšḳīdināšana jaunā kontekstā vai to saglabāšana sākotnējā veidolā, bet citā kontekstā.

\section{Vērtību objektivitāte un autonomijas ideāls}

Vērtību objektivitāte - attiecības starp vērtību un faktu ir otra nemainīgi aktuālā aksiolog̣ijas filozofiskā problēma, kas aktualizējas ne tikai pārejas sabiedrībās (un/vai posmos), bet ir nozīmīga vērtību izpratnei kā tādai, jo liek risināt vērtību definēšanas jautājumus. Fakti parasti tiek asociēti ar objektivitāti, bet vērtības ar subjektivitāti. Taču jebkura vērtība kḷūst par kultūras faktu tikai iemiesojoties, sākot ar vārdu, dzejoli, dziesmu u. tml., beidzot ar rīcību, attieksmi, attiecībām. Kultūra nav nekas cits kā iemiesotu vērtību pasaule.

${ }^{12}$ Berlins 1996b.
Pateicoties daiḷradei, cilvēciskās vajadzības savienojas ar vērtībām, un otrādāk - vērtības rada vajadzību pēc tām. Formālajā aksiologijā teorētisko viedokḷu plurālisms pastāv paralēli aksioloǵijas praktiskajai pusei, kura apraksta vērtību rašanos un izskaidro atškikirības starp dažādām vērtēšanas pozīcijām.

J. Berlins pārstāv vērtību objektivitātes individuālo pozīciju, kas tiek pamatota šādi: “ja cilvēks tiecas pēc kādas no šìm vērtībām, kuru es neuzskatu par savējo, es spēju saprast, kāpēc viņš pēc tās tiecas vai kā es justos, ja būtu pieņēmis tādu vērtību, dzīvodams viņa apstākḷos. Tas ir pamats cilvēku sapratnes iespējai. Es uzskatu, ka šīs vērtības ir objektīvas - proti, to raksturs un uzticība tām veido daḷ no cilvēka būtības, un tas ir objektīvs fakts". ${ }^{13}$ Berlins secina, ka tieši tāpēc plurālisms nav relatīvisms dažādās vērtības pastāv objektīvi, tās ir dala no cilvēces būtības, nevis patvalīigi radīiti cilvēku subjektīvās izdomas aug̣̣i. Līdz ar to respekts pret dažādām vērtību sistēmām ir iespējams, tas paver ceḷu iecietībai un liberālām sekām, kādas nevar izrietēt no monisma (pareizs ir tikai viens vērtību kopums, visas citas vērtības ir nepareizas) vai no relatīvisma (manas vērtības ir manas, tavas ir tavas, un, ja mēs nonākam sadursmē, loti žēl, bet neviens no mums nevar pretendēt uz pareizību). ${ }^{14}$ Arī par nacionālismu J. Berlins izsakās pozitīvi - apziņa par piederību pie kādas nācijas viņam šksiet pilnīgi dabiska un pati par sevi ne mazākā mērā nav nosodāma vai pat kritizējama. Tā ir patoloǵiska tikai tad, ja tiek novesta līdz ekstrēmismam.

Kā atzìmē politologs Ivars İjabs, vērtību horizonts ir "jau dots" un tiek pieṇemts kā objektīvs, jo mēs nevaram izvēlēties kaut ko vērtēt, sākot no šodienas, jo modernajā sabiedrībā vērtības konkrēto saturu iegūst patstāvīgi definētu interešu un individuālu lēmumu pastarpinājumā. Vērtību un interešu konflikts visbiežāk ir konflikts starp tām vērtībām, kuras konkrētajā situācijā rod atbalsi cilvēka interesēs, un tām, kas to nerod. Tas gan attiecas ne tik lielā mērā uz individuālajām, cik uz kolektīvajām vērtībām.

Tas, ko var uzskatīt par plurālisma jeb liberālajām vērtībām, ir nešaubīgi no apgaismības

\footnotetext{
13 Berlins 1996b.

14 Turpat.
} 
izaugušas, bet mūsdienās ievērojami transformējušās pozitīvā nozīmē. No minētās J. Berlina esejas izriet, ka par liberālajām vērtībām ir uzskatāmas šādas atziņas:

- dažādība ir laba;

- $\quad$ sabiedrība, kurā cilvēki ar atšķirīgiem uzskatiem ir iecietīgi cits pret citu, ir labāka nekā monolīta sabiedrība, kurā visiem tiek uzspiests viens uzskats;

- uz vienu jautājumu var būt vairāk nekā viena atbilde - proti, plurālisms;

- par vērtību pamatu jāuzskata motīvs, nevis sekas;

- būtisks ir patiesīgums, nevis panākumi. Turpinot liberālo vērtību uzskaitījumu ārpus konkrētās esejas, vēl ir jāmin šādas liberālās vērtības: indivīda autonomija un brīvība, cilvēktiesības un likuma vara. Šajā kontekstā nozīmīgi ir divi citi jēdzieni - pilsoniskums un pilsoniskā sabiedrība. Kāpēc? Atbildi uz šo jautājumu sniedz pats jēdziena "pilsoniskums" saturs, proti, pateicoties pilsoniskumam, indivīdi ir spējīgi domāt ne tikai par savām interesēm, bet arī par visas sabiedrības koplabumu. Un tā ir morāla orientācija, nevis pilsoniskuma ideologija, jo tāda orientācija pastāv visdažādākajās sabiedrībās. I. Ījabs, pētot pilsonisko sabiedrību, ir nonācis pie atziņas, ka pilsoniskums pastāv līdzās dažādu indivīdu un grupu interesēm, kuras savā starpā konfliktē. Pilsoniskums kā tikums veido dažādo interešu realizācijas fonu. I. İjabs apgalvo: "Tieši tā ir liberālās demokrātijas būtība: brīvas preses, biedrošanās brīvības, protestu utt. apstākḷıs izpaužas intereses, kas autoritāra režīma apstāklı os ir apspiestas un notušētas." ${ }^{15}$ Modernā sabiedrība ir individualizēta, jo balstās uz indivīda autonomiju, un reizē arī plurālistiska, jo pieņem uzskatu dažādību. Pētnieks uzsver, ka pilsoniskās sabiedrības ideāls paredz pilsoniskuma klātbūtni plurālistiskās interešu grupās sadalītā sabiedrībā. Tādējādi pilsoniskās sabiedrības jēdziens tikai padziḷina izpratni par liberāli demokrātisku valsti.

Lai dažādo interešu gūzmā respektētu atšķirīgās vērtības, ir skaidri jāapzinās tolerances faktiskās robežas. Bet jautājums par tolerances robežām ir neatbildēts ne tikai

15 Ijjabs 2012, 229.
J. Berlinam, tas ir savā būtībā neatbildams. Noteikt tā robežas nozīmē universalizēt kādu principu, bet tas savukārt dogmatizētu liberālās vērtības, kas būtu absurdi.

Pret vērtību relatīvismu vērsās arī viens no redzamākajiem eksistenciālisma filozofijas pārstāvjiem - Albērs Kamī, skaidri parādot, ka vērtību subjektivitāte tam, kurš tās aizstāv, ir būtiska eksistences jēgas noteiksme. Sevišksi spilgti tas izpaužas Mìta par Sīzifu beigu dạ̄ā: "Taču Sīzifs māca ne tikai augsto patiesību, kas noliedz dievus un vel akmenus. Arī viňš uzskata, ka viss ir labi. Šì pasaule .. viņa iztēlē nav nedz neauglīga, nedz niecīga. Katra akmens dalıiņa, katrs šā kalna iezis viņam noz̄̄mē visu pasauli. Cīna par virsotni var aizpildīt cilvēka sirdi. Tāpēc mums Sīzifs ir jāuzskata par laimīgu cilvēku." ${ }^{\prime 16}$ A. Kamī atsvešinātība nozīmē nevis nāvi, bet gan brīvību - brī̄ību radìt pašam savu pasauli un sevi. Eksistenciālisms pārliecību par brīvību un tiesībām uz savu pasaules skatījumu novieto pašā vērtību skalas virsotnē, uzsverot - cilvēka personiskā brīvība (fiziskā un garīgā) ir mūsdienu Rietumu cilvēka pamatvērtība. Pateicoties tai, mūsdienu cilvēks var īstenot personiskās autonomijas ideālu - cilvēkiem sava dz̄ive jāveido pašiem. Džozefs Razs par to saka: "Autonoms cilvēks ir savas dzīves autors vai līdzautors. Personiskās autonomijas ideāls ir vīzija, kurā cilvēki līdz noteiktai pakāpei paši regulē savu likteni un secīgu lēmumu veidā piešķir tam apveidus visas dzīves gaitā."17 Autonomija ir pašradīšanas ideāls, turpina Dž. Razs, jo autonoma cilvēka labklājību veido paša izvēlēto mērku un attiecību sekmīga īstenošana. Dž. Razs tādā veidā pauž individuālismu, kas raksturīgs liberālisma vērtību sistēmai. Neskatoties uz individuālisma trūkumiem, tā ir nepieciešamā pieeja vērtībām, ja vēlamies saprast, kā ir iespējama iecietība un līdz ar to vērtību plurālisms. Šeit ir vietā piebilst, ka, atškirīibā no J. Berlina, Dž. Razs runā par vērtību plurālismu kā par morālo plurālismu - uzskatu, ka pastāv dažādas dzīves formas un veidi, kuri atspoguḷo dažādus tikumus un ir nesavienojami. Tieši tāpēc iecietība ir būtiska sociàla vērtība, kas balstās uz cieņu pret citādību,

\footnotetext{
16 Kamī 1990, N 11, 32.

17 Razs 2001, 328.
} 
un bez tās nav iespējams izveidot spēcīgu un vienlaikus demokrātisku sabiedrību, kas spēj solidarizēties kopīgu mērḳu vārdā. Būt iecietīgiem nozīmē daḷēji ierobežot savu egoismu: savas šḳietami pašsaprotamās tiesības (patiesībā - tikai vēlmi) ien̄ist, noliegt un nepieņemt visu, kas nav saistīts ar mums pašiem. Taču tas nenozīmē bezgalīgu piekāpšanos, kas pakāpeniski pārvēršas par bezierunu pakḷaušanos, par kādu raksta Mišels Velbeks. Robežas var mēgināt nospraust ar universālu morāles principu palīdzību: pret morāli pareizu rīcību jāizrāda iecietība, bet pret amorālu - neiecietība. Bet arī tas ir risināms konceptuāli autonomijas un brīvības savstarpējo attiecību sasaistē.

Džozefam Razam nav ilūziju par cilvēka spējām - autonomija, un it īpaši autonoma dzīve, prasa noteiktu pašapziņas līmeni. Lai cilvēks spētu īstenot savu autonomiju, ir nepieciešami vairāki nosacījumi: atbilstošas garīgās spējas, noteikts izvēles iespēju diapazons un neatkarība. Neatkarība vispirms izpaužas pieņemtajos lēmumos, kas var būt par labu vēlmei pašapliecināties, kā arī pilnīgi pretēji - vēlmei to nedarīt. Autonomija prasa, lai cilvēkam būtu pieejamas daudzas morāli pieņemamas izvēles iespējas. ${ }^{18}$ Jebkāda vērtība rodas no izvēles, kuru pašu par sevi nevada vērtība, un tāpēc tā ir brīva, t. i., patvalịga. Notiek mijiedarbība starp neatkarīgo vērtību (jo noteiktas vērtības jau pastāv pirms mūsu ienākšanas šajā sabiedrībā) un vērtības pašradīšanu ar savas rīcības un savas pagātnes starpniecību. Šajā mijiedarbībā noteikta loma ir arī videi, jo tā var paplašināt autonomiju un tajā pašā laikā ietvert formas, kuras nebalstās uz izvēli, piem., kā uzsver Razs, vecāku un bērnu attiecības. Un vēl kategoriskākā formā viṇš apgalvo: "Personiskās autonomijas vērtība ir dzīves fakts. .. cilvēki, kas dzīvo kultūrvidē ar autonomijas tendencēm, var gūt panākumus tikai, būdami autonomi." 19 Autonomijas ideāls līdz ar to nav sasniedzams jebkurā vidē.

Autonomijas kā fundamentālas vērtības pozicionējums ved pie morālā plurālisma atzīšanas, un zināmās robežās respekts pret personisko autonomiju liek paciest sliktu vai launu rīcību. Dž. Razs lieto jēdzienu "konkurējošais plurālisms", ar to apzīmējot tādu tikumu vērtību, kuru esamība izraisa vēlmi nesamierināties ar noteiktiem trūkumiem citos cilvēkos, kaut arī viņiem piemīt vēl arī citi vienlīdz vērtīgi tikumi. Šādi spriedumi ḷauj secināt, ka visizplatītākās plurālisma formas ir konkurējošas. Tas savukārt rada konfliktus starp cilvēkiem, kuri tiecas pēc vērtīgām, bet nesavienojamām dzīves formām. Lai konflikti nepārvērstos par ikdienas dzīves neatņemamu sastāvdalu, Dž. Razs uzskata, ka iecietības un autonomijas respektēšanas pienākumi rada virkni citu pienākumu, kas nepieciešami autonomas dz̄̄ves īstenošanai un kas ir mūsu pienākums pret citiem cilvēkiem. Tas ir

- pienākums veicināt izziṇas spējas - spējas uznemt, atcerēties un izmantot informāciju;

- pienākums attīstīt rakstura īpašības, kas noderīgas autonomai dzīvei, - stabilitāti, lojalitāti, pieķeršanās spējas, prasmi saglabāt tuvas attiecības;

- pienākums radīt atbilstošu izvēḷu diapazonu, lai cilvēkam būtu, no kā un ko izvēlēties.

Dž. Razs, tāpat kā J. Berlins, lieto jēdzienu "pozitīvā brīvība": cilvēki pamatā uzlūkojami par autonomām būtnēm - par vērtîbu radītājiem. Abi domātāji ir vienisprātis par to, ka vārda "brīvība" satvars ir saistīts ar indivīda vēlēšanos būt noteicējam par sevi: "Vēlos, lai manu rīcību noteiktu manis paša, nevis citu cilvēku griba. Vēlos būt subjekts, nevis objekts; vēlos, lai mani vadītu paša izdarīti spriedumi un apzināti mērḳi, nevis apstākḷi, kas ietekmē mani no malas." ${ }^{20}$ No apstākḷu varas diemžēl nav izdevies atbrīvoties nevienam, tāpēc jāatzīst, ka pilnīga pašnoteikšanās ir iespējama tikai vēlmju līmenī. Tajā pašā laikā cilvēkā šī tieksme būt iespējami mazāk atkarīgam ir nemainīgi klātesoša. J. Berlins aplūko divas galvenās formas, ko vēsturiski ir ieguvusi vēlēšanās pašam vadīt savu dzīvi:

- pirmā ir pašnoliegums, lai iemantotu neatkarību;

- otrā - pašapliecināšanās jeb pilnīga sevis identificēšana ar konkrētu principu vai ideālu, lai sasniegtu tādu pašu mērķi.

\footnotetext{
${ }^{20}$ Razs 2001, 349.
} 
Atškirīibā no J. Berlina, Dž. Razs uzskata, ka pozitīvai brīvībai piemīt iekšēja vērtība, kas izriet no tās ieguldījuma personiskajā autonomijā. Cilvēka pozitīvo brīvību veicina viss, kas vien kāpina viņa spēju dzīvot autonomu dzīvi. Brīvības doktrīna savukārt balstās uz autonomijas un vērtību plurālisma svarīgumu. Sekojot Raza domu gājienam, ir skaidri jāapzinās, ka brīvība neietver morāli slikto un atbaidošo: "Tā kā autonomija ir vērtīga tikai tad, ja tā ir vērsta uz labo, tai nav nekāda iemesla sagādāt un aizstāvēt nevērtīgas vai vēl jo mazāk sliktas izvēles iespējas." 21 Tajā pašā laikā ir redzama arī medaļas otrā puse - cilvēks ir autonoms pat tad, kad viņš izvēlas slikto, autonomija ir daḷēji akla pret pieejamo izvēles iespēju kvalitāti. Cilvēks ir autonoms tikai tad, ja tic, ka viņam ir pieejamas vērtīgas izvēles iespējas. Protams, ka autonoma cilvēka "sliktās izvēles" padara viṇa eksistences kvalitāti apšaubāmāku par neautonomas dzīves kvalitāti, precīzāk būtu teikt - mazvērtīgāku. Raza secinājums par autonomijas un brīvības sasaisti ir izsakāms cēloņsakarības formā: cilvēki var veiksmīgi baudīt autonomu dzīvi tikai tad, ja viņi dzīvo vidē, kura atbalsta piemērotas sociālās formas.

Tā kā vērtības ir iemiesotas konkrētās sociālās formās, nevar runāt par radikālu politisko rīcību, lai nodrošinātu sociālo apstākḷu būtisku pārmaiṇu: "Politika ir pakāpenisku uzlabojumu māksla." 22 Tas ir diskutabls apgalvojums, kurš ir patiess attiecībā uz vērtību funkcionēšanas veidu, jo brīvība ir demokrātijas imanenta pazīme. Ja vērtības socializācijas gaitā nav tapušas intrinsiskas, tās tiks realizētas kā sabiedrības noteiktas normas, no kurām nav iespējams izvairīties, bet kuras indivīds var uzskatīt par nebūtiskām.

\section{Multikulturālisms un tolerances ideāls}

Multikulturālisma ietekmē arī nācijas identitātes un nacionālisma saturs, kā arī tā izpratne ir ievērojami mainījusies. Nācijas vairs nav un īsti arī nevar būt pilsoniski viendabīgas migrācijas procesu dēḷ. Savējā un svešā pretnostatîjums jeb citādības uzsvērums ir

\footnotetext{
21 Razs 2001, 364.
}

22 Turpat, 377. faktors, kas raksturo un vienlaicīgi arī veido nacionālo identitāti. Šajā ziṇā īpaša loma ir postmodernisma māksliniekiem, kuri "vēršas pie sabiedrības, lai parādītu, kā citādība jūtas no iekšpuses. Var uzskatīt, ka postmodernisms nodarbojas ar citādības artikulāciju". ${ }^{23}$ Lai arī pārspīlēts, tomēr tas ir uz postmodernisma kultūras izpausmēm un specifiku attiecināms apgalvojums. Tajā pašā laikā postmodernajā sabiedrībā dominējošā centra neesamības dēl (pret ko strukturēt savu atšķirību) katrs indivīds var atseviški definēt savas attiecības ar citādo. ${ }^{24}$ To gan nevar apgalvot par Latviju un situāciju Latvijā, jo pētnieciskās darbības rezultātā vēl ir jāpierāda, kādā attīstības pakāpē atrodas Latvijas sabiedrība, vai tā jau būtu uzskatāma par postmodernu sabiedrību, ja tajā ir vērojamas atsevišksas postmodernisma paz̄mes kultūrprocesos, kas par to varētu liecināt. Analizējot postmodernismu un modernismu, V. Čakare izsaka pienēmumu, ka Latvijas sabiedrībā dominē tradicionālā un modernā apziņa. Līdz ar to kultūras piederība ir nevis indivīda paša izvēles rezultāts, bet gan "dots lielums" un jaunlaiku postmodernā ideologija tiek dēstīta nepostmodernā realitātē, raisot ne vien psihologiskas pretrunas, bet arī ideologisku konfliktu. ${ }^{25}$

Pie iepriekš teiktā vēl jāpiebilst, ka problēmu saasina apstāklis, - postmodernajā sabiedrībā neveidojas noturīgas un ilglaicīgas identitāšu grupas. Latvijas mūsdienu situācijā relatīvi noturīgas identitāšu grupas ir politiskās partijas, kuras reprezentē attieksmi pret citādo amplitūdā no pilnīga nolieguma, kategoriskas neiecietības līdz pretrunīguma konstatācijai, atšķirīgu pozīciju atz̄̄̌sanai un, visbeidzot, relatīvai tolerancei. Par to liecina, piem., Ilzes Šulmanes pētījums par neiecietības diskursu Saeimas politiķu runās, analizējot 6.,7. un 8. Saeimas stenogrammas. ${ }^{26}$ Pētniece pamatoti uzskata, ka sabiedriski politiskā situācija - attiecības starp dažādām iedzīvotāju grupām - pēc 1998. gada varēja stabilizēties (izcēlums mūsu - V. S.), taču izglīitības reforma konfrontēja politiķus un sabiedrību no

\footnotetext{
23 Rutkēviča 2004, 54.

24 Turpat, 55.

25 Čakare 2004, 31.

26 Šulmane 2007.
} 
jauna, kas, iespējams, izraisīja dezintegrācijas procesus un tolerances samazināšanos sabiedrībā. I. Šulmane nonāk pie secinājuma, ka parlamentārajā runā dominē izslēdzošs, neiecietīgu runu raksturojošs un neiecietību veicinošs diskurss, īpaši par tēmām un problēmām, kas sabiedrībā tiek vērtētas pretrunīgi. Viņasprāt, gan politiķu rīcība (lēmumi un reakcija uz citu grupu mēǵinājumiem paust savu viedokli), gan politiskais diskurss medijos un Saeimas sēdēs liecina par neiecietības eskalāciju un izslēdzošu diskursu tiražěšanu publiskajā telpā, kas neatbilst sabiedrības vairākuma noskaņojumam. Arī I. İjabs, pētot morālo retoriku 7. un 8. Saeimas stenogrammās, nonāk pie identiskiem secinājumiem, t. i., morālajā retorikā dominē konfrontējoša orientācija. Vārdi, kas saistîti ar morāli un ētiku, lielākoties tiek izmantoti, lai morāli degradētu politisko oponentu, savukārt moralizēšana tiek izmantota par oponenta diskreditācijas un izslēgšanas instrumentu. Pretstatā oponenta diskreditācijai, pētnieks uzsver to, kā vajadzētu būt, - debates pat visagresīvākajās formās pretējo pusi nevis izslēdz, bet gan iekḷauj kopīgā, plurālistiskā komunikācijāa. ${ }^{27}$ Arī citi Saeimas stenogrammu pētnieki pauž pārliecību, ka sabiedrības saskaņai visvairāk traucē politiķu aktivitātes, agresīvi izteikumi. Ja deputāti debatēs spētu pakāpeniski iedzīvināt demokrātiskai politiskajai kultūrai raksturīgu savstarpējo komunikāciju, tas noteikti dotu būtisku pozitīvu impulsu Latvijas virzībā uz efektīvi funkcionējošu un issteni demokrātisku politisko režīmu. ${ }^{28}$

Tolerance ka vērtība un cieña pret atškirīga viedokḷa paudēju Latvijas politiskajā diskursā ir drīzāk izņēmums, nevis ikdienas situācija, tāpēc šīs vērtības ir jācenšas iedzīvināt ar katrām nākamajām Saeimas vēlēšanām, kurās tīri kvantitatīvi varētu palielināt toleranti diskutēt spējīgu deputātu skaitu. Bet tā jau ir mūsu - vēlētāju - atbildība un tālredzīga izvēle. Jāṇem vērā, ka Latvijas situācijā tas ir uzdevums ne tikai valstij, bet arī tai iedzīvotāju daḷai, kura ir uzskatāma par pilsonisko sabiedrību.

Šì uzdevuma veikšanā, no vienas puses, ir jārespektē valsts centieni īstenot praksē (ne

\footnotetext{
27 Ijabs 2007b, 66-67.

28 Turpat, 133.
}

tikai integrācijas plānos) integrācijas politiku, no otras puses, jārēḳinās ar šīs politikas jau pieḷautajām kḷūdām tās realizācijas gaitā. Var pievienoties Ilzes Vasariņas vērtējumam par multikulturālisma iespējām Latvijā - tas ir atkarīgs no konkrētās sabiedrības attieksmes, vērtību sistēmas un tolerances līmena, cienas, vēlmēm un mērksiem, no ikviena cilvēka unikālās personiskās un kultūru daudzveidības pieredzes. ${ }^{29}$ Etniskā un kultūru dažādīiba ienāk katra indivīda dzīvē caur personiskajiem pārdz̄ivojumiem un reālām attiecībām ar cilvēkiem, kas pārstāv dažādas etniskās kultūras. I. Vasariņa analizē multikulturālisma iezīmes dzīvesstāstos un uzsver būtisku iezīmi, kas nepieciešama multikulturālisma attīstībai, svarīgi, lai katra sabiedrības etniskā grupa izjustu lepnumu par savu kultūru un tradīcijām. Teorētiski, viņasprāt, multikulturālisms nekādā ziṇā nav pretrunā ar nacionālas valsts un nacionālas pašapzinias ideju. Taču realitātē lielākoties nacionālie mērḳi un institūcijas ir ārpus privātā un individuāli nozīmīgā interešu lauka. Savukārt par politiskās retorikas un priekšvēlēšanu kampaņu neiztrūkstošu sastāvdaḷu ir kḷuvis sauklis par latviešu valodas un tradicionālo kultūras vērtību saglabāšanu abos - Latvijas un Eiropas - kontekstos.

Pretēja viedokḷa paudējs ir Āzijas studiju speciālists prof. Leons Taivāns, kurš uzskata, ka multikulturālisms un integrācijas politika ir piln̄̄gi izgāzušies un Eiropa ir sadalījusies divās naidīgās nometnēs: musulmaņi un pārējie. Semjuela Hantingtona un citu globālo procesu pētnieku piesauktā "civilizāciju sadursme", neraugoties uz kritiku no integrācijas politikas atbalstītāju puses, realizējas. "Nacionālo valstu vairs nav - valsts sapnis ir izsapnots! Dānija, Nīderlande, Anglija, Francija - tās ir daudznacionālas valstis. Arī Latvija ir divkopienu, nevis nacionāla valsts. Kādreiz konfrontācijas līnija gāja pa robežām, tagad tā iet cauri valstij." ${ }^{30}$ Tieši ši situācija, tāpat kā diametrāli pretēji profesionāḷ viedokḷi, liek domāt par to, ka cīṇa par vērtībām ir ne tikai mūsdienu realitāte, bet arī nākotnes perspektīva.

Tāpēc viens no svarīgākajiem brīva pilsoņa pienākumiem ir aizstāvēt fundamentālās

\footnotetext{
29 Vasarina 2007.

30 Taivāns: "Nacionālās valsts sapnis .." 2017.
} 
vērtības, citādi nav pamata apgalvot, ka tās tiešām ir dārgas. Ja par vērtību tiek pasludināta, piem., cilvēcība (ar kuru jāsaprot arī brīvība, mīlestība, cieņa, tolerance utt.), tad par to ir jāiestājas brīēi, kad šī vērtība tiek apdraudēta. Pretējā gadījumā apgalvojumi par šîs vērtības nozīmi ir tikai tukši vārdi. Ko nozīmē aizstāvēt vērtības? Pirmkārt, tas nozīmē kritisku domāšanu un analīzi, kuras mērkis ir uzmanīgi sekot līdzi tam, kā konkrētas vērtības tiek (vai netiek) īstenotas praksē. Otrkārt, ja ir skaidrs, ka vērtības tiek apdraudētas, tad ar to nedrīkst samierināties - par to ir jārunā publiski. Treškārt, lai panāktu vērtību sistēmas maiņu vai nostiprinātu vērtību statusu sabiedrībā, tās ir jāpraktizē. Liela nozīme ir tam, ka vērtības praktizē publiski pazīstamas personas, kuras izmanto savu autoritāti, lai kḷūtu par iedrošinājumu citiem. Vērtību praksē ir būtisks arī kvantitatīvais aspekts - jo vairāk cilvēku praktizē kādas konkrētas vērtības, jo plašāka veidojas sociālā vide, kur šìs vērtības ir nostiprinājušăs kā norma. ${ }^{31}$

Situācijās, kad praktizētās vērtības jau nostiprinājušās kā norma, tās sāk kalpot par lìdzekli citu vērtību uzturēšanai. Runa ir vispirms par kultūras vērtībām. Kādām tieši? Viedokḷi atškiriras, bet I. İjabs ${ }^{32}$, piem., par nozīmīgākajām eiropeiskām kultūras vērtībām, min kristietību, apgaismību, iekšêjību, ironiju un vēsturiskumu. Kristietība Eiropā joprojām veido nozīmīgu Eiropas kultūras un politikas horizontu l,oti daudzos aspektos, kas sadzīvo ar citiem orientieriem, uz kuriem ir balstīta modernā Eiropa, - sekulāru humānismu un toleranci. Viena no kristīgas izcelsmes Eiropas vērtībām ir cilvēka iekšējā dzīve jeb iekšējība. Vienlaikus iekšējība, uzsver I. İjabs, ir arī politisks fenomens - uz to balstās cilvēku priekšstats par publiskā un privātā attiecībām, par nepieciešamību respektēt ikviena atsevišksa indivīda sirdsapziṇu un garantēt viņam tiesības uz privāto dzīvi. Līdzīgi kristietībai, arī apgaismība Eiropas kultūrā ir kaut kas vairāk par vērtību radīšanas fenomenu - tā ir intelektuāla kustība, kas joprojām ievērojamā mērā nosaka eiropeiskos priekšstatus par cilvēka un sabiedrības attiecībām. Ironija ir svarīga tāpēc, ka tā dod iespēju paplašināt "horizontus" - paskatîties uz sevi un lietām no cita skata punkta. Vēsturiskums ir forma, kuras ietvaros Eiropas kultūra ir paradusi skaidrot sociālos, politiskos un kultūras fenomenus. Vairākumam eiropiešu vai eiropeiski domājošiem indivīdiem ir raksturīga pārliecība, ka ikvienas norises jēga ir iepazīstama, uzlūkojot tās vēsturisko attīstību.

\section{Dzīvesstāsti un krīzes pēcgarša}

Dzīvesstāsti (naratīvi) liecina par pārmaiņām vērtību izpratnē ilgstošā laika posmā, tāpēc tie ir būtisks informācijas avots vērtíbu pētniecībai mūsdienās. Piem., sešos no I. Vasariņas pētītajiem dzīvesstāstiem parādās kopīga raksturīga iezīme - tie, kas sevi uzskata par latviešiem, latviskumu sākuši izkopt tikai pirms 3-5 paaudzēm. Autore uzsver, ka savas etniskās izcelsmes un kultūras pozitīvais pašnovērtējums (izcēlums mūsu - V. S.) ir tieši tas, kas dzīvesstāstu autoriem ḷauj lūkoties uz citu etnisko grupu pārstāvjiem kā uz līdzvērtīgiem, ja runa ir par vinu tradīcijām un uzskatiem. ${ }^{33}$ Tajā pašā laikā iezīmējas būtiskas atšḳirības Latvijas un trimdas dzivesstāstos. Trimdas latviešu stāsti liecina par Rietumu kultūras klātbūtni, līdz ar to tie ir vairāk organizēti, hronoloǵiskāki, atbilstošāki t. s. attīstîbas naratīviem. Skumjas par pamesto dzimteni mijas ar prieku par jauno dzīvi. Savukārt fragmentārais modelis dominē Latvijas dzīvesstāstos. Tas ir skaidrojams ar padomju laikam raksturīgo pretrunu starp ideoloǵiski atzītām un personiski nozīmīgām vērtībām..$^{34}$ Faktiski padomju laikā pastāvēja vismaz divas atškiirīgas vērtību grupas: ideologiski atzītās un personiski nozīmīgās, kam var pieskaitīt arī trešo grupu, ko pārstāvēja cilvēki, kas ideolog̣iski atzītās vērtības uzskatīja par savas personiskās dzīves vērtībām, uz kurām balstās normas un ideāli, precīzāk, vērtību ideāli.

Baiba Bela salīdzina Latvijas un trimdas latviešu dzīvesstāstus, uzsverot, ka pēdējie ir fragmentēti, jo padomju laikā klusēšanas vērtība bija divkārša: klusēšanas kultūra un tēlains

\footnotetext{
33 Vasarina 2007, 331

34 Turpat, 332.
}

31 Sîlis 2015.
$32 \quad$ Ijabs 2007a. 
izteiksmes veids bija izdzīvošanas nepieciešamība. ${ }^{35}$ Tas attiecināms galvenokārt uz vecāka gadagājuma cilvēkiem. Latvijā nacionālā dimensija ir noteicošā, ņemot vērā šo valsts vēsturisko pieredzi. Jaunākiem ir raksturīgs ne tik daudz slēgtais, cik atvērtais naratīvs.

Līdzīgi kā iepriekšējā gadsimtā, arī 21. gs. pētnieku skatījums uz vērtībām nav pārāk iepriecinošs. To pārliecinoši ilustrē jēdziena "anomija" lietojuma izplatîba. Tā, piem., Agita Misānes pats raksta nosaukums jau skan kā spriedums "Anomija kā laikmeta un sabiedrības diagnoze" ${ }^{36}$. Autore gan neraksturo situāciju, drīzāk apkopo uzskatus par anomijas izpratni, nonākot pie secinājuma, ka anomijas jēdziens raksturo disharmoniskas indivīda un plašākas sabiedrības attiecības, savstarpēju neuzticēšanos, nespēju vienoties par kopīgām vērtībām (izcēlums mūsu - V. S.), sociālo normu un sociālo institūciju vājumu. Būtisks ir autores vispārinājums, ka šis stāvoklis ir raksturīgs visām pārejas sabiedrībām, bet sabiedrībai šis destruktīvais periods jāspēj saīsināt. Vai Latvijas sabiedrība ir uzskatāma par pārejas sabiedrību? Tagadnes kontekstā tā ir pārejas sabiedrība no krīzes uz pēckrīzes posmu, ja uzskatām, ka pēdējais ir sācies, pārvarot 2008.-2009. gada ekonomiskās un finanšu krīzes sekas. ${ }^{37} \mathrm{Ka}$ apgalvo ekonomists D. Zelmenis, neplānotā Parex bankas glābšana 2008. gada beigās praktiski sagrāva valsts finanses. Un šī ekonomiskā un finanšu krīze ir pārvarēta Latvijas iedz̄ivotājiem sāpīgā un nedraudzīgā veidā. ${ }^{38}$ Var ilgi diskutēt, vai krīze jau ir beigusies vai vēl turpinās, taču viens ir skaidrs - Latvijas sabiedrība garīgi un materiāli ir cietusi, tāpēc anomija, pārfrāzējot A. Misānes teikto, ir Latvijas šodienas sabiedrības diagnoze, vērtību jomā tai skaitā.

Lielākā daḷa ES valstu pārdzīvoja 2008.2009. gada globālo ekonomisko krīzi kā labklājības valstu krīzi, kas rada savu izpausmi pārsvarā ar politiskās krīzes iezīmēm, uz ko, mūsuprāt, pamatoti norāda K. Landa: "Eiropas krīze .. ir politikas, nevis garīguma, kultūras vai morāles krīze. Krīzes cēlonis ir Eiropas nespēja atbildēt uz eiropiešu bažām par nākotnes riskiem, īpaši krīzes laikā un valstīs ar stingru labklājības tradīciju." ${ }^{39}$ Turpretim Latvijas situācija ir daudz pretrunīgāka un negācijām bagātāka.

Eiropas Parlamentā esošās Tautas partijas grupas Igaunijas delegācijas vadītājs Tunne Kelams savā intervijā Latvijas Avīzei parādīja saistību starp pēckara krīzi un 2008./2009. gada krīzi, uzsverot, ka patiesā ES integrācijas ideja ir miers, stabilitāte, pēc iespējas lielāka vienlīdzība un solidaritāte. "Un krīze mums atgādina par šīm pamatvērtībām. ES izveidoja izmisušas, nevis bagātas valstis. Tām nebija citas izvēles [..] esmu optimistisks, ka pārvarēsim šo krīzi un ka š̄i ir iespēja pārvērtēt mūsu vērtības, kuras nedrīkst balstīt tikai patērinšs." ${ }^{40}$ Tā kā Latvija nav pieskaitāma pie valstīm ar stingru labklājības tradīciju, rodas šaubas, vai Latvijas situāciju maz iespējams raksturot tikai kā vienas jomas, piem., politisko, krīzi, vai arī ir saskatāmas garīgo, tai skaitā morālo, vērtību krīzes pazīmes. Latvijā īstenotā ekonomiskās krīzes pārvarēšanas politika ir veicinājusi daudz lielāku visaptverošu krīzi nekā labklājības valstīs, radot nedrošības sajūtu par šodienu un pesimismu par nākotnes perspektīvām - iespējām uzlabot savu labklājības līmeni un līdz ar to arī iespējām nodrošināt savu "garīgo komfortu" kaut vai minimālā apjomā - kā paḷāvību un uzticēšanos sociālajām institūcijām. Minētais ir attiecināms uz visām iedzīvotāju grupām. Krīzes ietekmes objektīvais raksturojums, saskan̄ā ar statistikas datiem, liecina par bezdarba, nabadzības un nevienlīdzības pieaugumu. Visvairāk skumdina fakts, ka ir pieaudzis nabadzības risks bērniem un jauniešiem, kā arī tas, ka krīze viskrasāk izjusta kā darba un ienākumu zaudējums. Apzinoties šīs situācijas dramatismu, socioloǵes T. Lāce un R. Rungule, ir spiestas atzīt, ka, pieaugot nabadzībai, pieaug arī sociālā atstumtība un "var veidoties tā saucamā zaudētā paaudze, kas nespēs sevi pilnībā realizēt". ${ }^{41}$ Tas vēl vairāk aktualizē jautājumu par kopējām vērtībām, kuras varētu

\footnotetext{
39 Lands 2016,54.

40 Igaunijas eiroparlamentārietis .. 2016.

${ }^{41}$ Lāce, Rungule 2016.
} 
mazināt polarizācijas atsvešinātības pakāpi ne tikai starp eliti un pārējiem iedzīvotājiem, bagātajiem un nabagajiem, bet arī starp amatiem un statusa ieguvējiem.

Bet kopējās vērtības var ietekmēt procesus, ja tās pašas funkcionē kā telpā un laikā sakārtotas sociālās prakses. Atsaucoties uz E. Gidensa strukturācijas teoriju, var apgalvot, ka kopējās vērtības ir pašatražojošas sistēmas, kas funkcionē kā struktūras, - noteikumu un resursu kopums, kura centrā ir reflektējošs indivīds - darbības veicējs. Bet cilvēku darbībām ir raksturīga rekursivitāte. Tas nozīmē, ka darbības tiek atražotas, izmantojot tos pašus līdzekḷus, ar kuru palīdzību cilvēki var izteikt sevi kā darbības veicējus: "Ar savām darbībām un to laikā indivīdi atražo nosacījumus, kas padara šîs darbības iespējamas." ${ }^{\prime 4}$

Tas pilnā mērā ir attiecināms uz vērtībām, jo indivīdi kā sociālo prakšu īstenotāji ir nepārtraukti līdzdalīgi procesos, kuros paši atražo vērtības. Jautājums ir tikai par to, kādas ir šīs vērtības.

\section{Nobeigums}

Kopš ir izveidota Eiropas Savienība, plurālisms un tolerance ir "vērtību projekta"

42 Gidenss 1999, 35. sastāvdaļas, bez kurām š̄ savienība nemaz nevar pastāvēt. Ja vērtības netiek praktizētas un iemiesotas cilvēka, sabiedrības un valstu attiecībās, tās ir deklaratīvas, tukšas, reizēm pat bīstamas - tās kḷūst par manipulācijas instrumentu politiskajās cīṇās. Vienlaikus vērtības, kas tiek patiesi un plaši praktizētas, veido patstāvīgas struktūras, kas iemanto relatīvu stabilitāti, rezultātā nodrošinot arī sabiedrības ilgtspēju.

Lai minētās vērtības no deklaratīiām pārtaptu par ikdienas sociālajām praksēm, ir vajadzīga izvēles brīvība, kuru spēj īstenot tikai un vienīgi autonoms indivīds, kura labklājības līmenis ir pamats tam, lai viņš sāktu darboties arī koplabuma vārdā. Autonomija ir galvenais priekšnosacījums, lai vērtības būtu gan līdzeklis, gan mērkiis patstāvīgas eksistences nodrošināšanai. Aiz tā seko nākamais solis - autonomi indivīdi apzinās brīvības, neatkarības un drošības vērtību. Un vēl nākamais - apzinoties šo, viṇi var kḷūt par aktīviem pilsoniskās sabiedrības veidotājiem, tādējādi pārvarot krīzes sakāpināto anomiju attiecībā pret valsti. Individuālās stratēgijas bija līdzeklis krīzes pārvarēšanai, bet kolektīvās stratēgijas kā pilsoniskuma izpausmes ir demokrātijas nostiprināšanas līdzeklis pēckrīzes posmā, joprojām pamatojoties uz kopējām eiropeiskām vērtībām.

\section{VĒRES}

Bela, B. (2007) Stāsta dzīve valodā: naratīvās stratēǵijas Latvijas un trimdas dzīvesstāstos. Zirnīte, M. (sast.) Dzīvesstāsti: vēsture, kultūra, sabiedrība. Rīga : LU Literatūras, folkloras un mākslas institūts.

Berlins, J. (1996a) Brīvība. Fragments no esejas "Mans intelektuālais ceḷš". Pieejams: http://www.satori.lv/ raksts/11356/Jesaja_Berlins/Briviba (14.09.2018.).

Berlins, J. (1996b) Plurālisms. Fragments no esejas "Mans intelektuālais ceḷšs". Pieejams: http://www.satori. lv/raksts/11377/Jesaja_Berlins/Pluralisms (14.09.2018.).

Berlins, J. (2000) Četras esejas par brīvību. Rīga : Sprīdītis.

Čakare, V. (2004) Postmodernisms un modernisms. Radzobe, S. (sast.) Postmodernisms teātrī un drāmāa. Rìga : Jumava.

Dzalbe, I. (2015) Vērtības. Vents, S., Žabicka, A. (sast.) Filosofiskā antropologija I. Rīga : RSU.

Igaunijas eiroparlamentārietis: krīzes cēlonis ir vērtību trūkums (2012) Pieejams: http://www.la.lv/igaunijaseiroparlamentarietis-krizes-celonis-ir-vertibu-trukums-2/\# (14.09.2018.).

İjabs, I. (2007a) Eiropas integrācijas vērtību dimensija. Ozoliṇa, Ž. (red.) Latvijas skatījums uz Eiropas Savienības nākotni. Rīga : Latvijas Valsts prezidenta kanceleja.

İjabs, I. (2007b) Morāla retorika 7. un 8. Saeimas stenogrammās. Rozenvalds, J. (red.) Parlamentārais diskurss Latvijā: Saeimas plenārsēžu stenogrammu datorizètā analīze. 
İjabs, I. (2012) Pilsoniskā sabiedrība. Rīga : LU Akadēmiskais apgāds.

Kamī, A. (1990) Mīts par Sīzifu. Grāmata. 1990. gada novembris.

Klīve, V. V. (1998) Rīcības celsos. Rīga : Zinātne.

Lands, K. (2016) Kādu krīzi piedzīvo Eiropa? Politiskie principi un labklājīibas valsts. Kruks, S. (red.) Ekonomiskā krīze Latvijā: veiksmes stāsta pēcgarša. Rīga : RSU, 45-56.

Lāce, T.; Rungule, R. (2016) Ekonomiskās krīzes ietekme uz sabiedrību un krīzes mācības. Kruks, S. (red.) Ekonomiskā krīze Latvijā: veiksmes stāsta pēcgarša. Rīga : RSU, 97-123.

Misāne, A. (2016) Anomija kā laikmeta un sabiedrības diagnoze. Kulē, M. (zin. red.) Vērtības: Latvija un Eiropa, 1. sēj. Rīga : LU Filozofijas un sociologijas institūts, 297-308.

Razs, Dž. (2001) Brīvības morāle. Rīga : Madris.

Russell, B. (1938) Power. A New Social Analysis. London : Routledge.

Rutkēviča, A. (2004) Nacionālā identitāte un postmodernā sabiedrība. Radzobe, S. (sast.) Postmodernisms teātrī un drāmā. Rìga : Jumava.

Sīlis, V. (2015) Aizstāvēt vērtības - kādas un kāpēc? Domuzìme, Nr. 1, 58.

Šulmane, I. (2007) Neiecietības diskurss Saeimas politiku runās. Rozenvalds, J. (red.) Parlamentārais diskurss Latvijā: Saeimas plenārsēžu stenogrammu datorizētā analīze. Rīga : LU Akadēmiskais apgāds, 69-91.

Taivāns: "Nacionālās valsts sapnis ir izsapnots! Notiek karš" (2017). Pieejams: http://www.tvnet.lv/zinas/ viedokli/652964-taivans_nacionalas_valsts_sapnis_ir_izsapnots_notiek_kars_(14.09.2018.).

Vasarina, I. (2007) Multikulturālisma iezīmes dzīvesstāstos: divkopienu sabiedrība vai multikulturālisms? Zirnīte, M. (sast.) Dzīvesstāsti: vēsture, kultūra, sabiedrība. Rīga : LU Literatūras, folkloras un mākslas institūts, 324-335.

Vējš, J. N. (2016) Jesaja Berlins un vērtību problemātika Latvijas kontekstā. Vērtības: Latvija un Eiropa, 1. sēj. Vērtību pētījumi - filozofiskie aspekti. Rīga : LU Literatūras, folkloras un mākslas institūts.

Ziṇu aǵentūra LETA (2018) Meja teroraktu Londonā nosauc par slimu un samaitātu. NRA (23.03.2018.). Pieejams: http://nra.lv/politika/pasaule/204701-meja-teroraktu-londona-nosauc-par-slimu-un-samaitatu. htm (14.09.2018.).

Zelmenis, D. (2016) Krīžu teorijas un Latvijas realitāte. Kruks, S. (red.) Ekonomiskā krīze Latvijā: veiksmes stāsta pēcgarša. Rīga : RSU. 